\title{
Bromeliad-associated mosquitoes from Atlantic forest in Santa Catarina Island, southern Brazil (Diptera, Culicidae), with new records for the State of Santa Catarina
}

\author{
Gerson Azulim Müller \& Carlos Brisola Marcondes
}

Departamento de Microbiologia e Parasitologia, Centro de Ciências Biológicas, Universidade Federal de Santa Catarina, 88040-900 Florianópolis, Santa Catarina, Brasil (gecoazul@hotmail.com, cbrisola@mbox1.ufsc.br)

\begin{abstract}
Bromeliad-associated mosquitoes (Diptera: Culicidae) in Atlantic Forest in Florianópolis, Santa Catarina, southern Brazil, were studied, examining plants of Vriesea philippocoburgi Wawra and Aechmea lindenii (E. Morren) Baker var. lindenii at secondary Atlantic rain forest, and A. lindenii and Vriesea friburgensis Mez var. paludosa (L. B. Smith) at "restinga" per month, during 12 months. No immature forms of mosquitoes were collected from $A$. lindenii in the secondary forest. Collections obtained 368 immature mosquitoes, none of them from A. lindenii from rain forest. Culex (Microculex) spp. constituted $79.8 \%$ of the total, Wyeomyia (Phoniomyia) spp. $17.93 \%$, and Anopheles (Kerteszia) cruzii (Dyar \& Knab, 1908) only 1.36\%. The study shows the great predominance of species of medical importance not yet proved, and the small number of immature stages of anopheline mosquitoes. The rainfall, but not the mean temperatures, significantly influenced the quantity of mosquitoes from $V$. philippocoburgi. Significant differences between the quantities of immature forms of all the bromeliad species were found, and the shape of the plants could be important to the abundance of mosquitoes. All six species of $C x$. (Microculex) found are recorded for the first time in the State of Santa Catarina, and all six species of Wyeomyia (Phoniomyia) are recorded for the first time in bromeliads in this state.
\end{abstract}

KEYWORDS. Atlantic Forest, phytotelmata, Anopheles, Wyeomyia, Culex.

RESUMO. Mosquitos associados a bromélias em Mata Atlântica na Ilha de Santa Catarina, sul do Brasil (Diptera, Culicidae), com novos registros para o Estado de Santa Catarina. Mosquitos (Diptera: Culicidae) associados a bromélias em Mata Atlântica na Ilha de Santa Catarina, no Estado de Santa Catarina, foram estudados. Foram examinadas mensalmente plantas de Vriesea philippocoburgi Wawra e Aechmea lindenii (E. Morren) Baker var. lindenii de floresta atlântica pluvial ombrófila e A. lindenii e Vriesea friburgensis Mez var. paludosa (L. B. Smith) de restinga, durante 12 meses. As coletas resultaram em 368 formas imaturas de mosquitos, sendo que nenhuma foi coletada em A. lindenii de mata ombrófila. Culex (Microculex) spp. constituíram 79,8\% do total, Wyeomyia (Phoniomyia) spp. 17,93\% e Anopheles (Kerteszia) cruzii (Dyar \& Knab, 1908) apenas 1,36\%. O estudo mostra a predominância de espécies de importância médica ainda não comprovada e a raridade de formas imaturas de anofelíneos. A pluviosidade, mas não a temperatura, influenciou positivamente a quantidade de formas imaturas em V. philippocoburgi. Este fator e a temperatura não influenciaram as quantidades obtidas em outras bromélias. Foram encontradas diferenças significativas na densidade de formas imaturas nas diferentes espécies de bromélias, sendo ressaltada a possível influência da forma da planta na abundância dos insetos. As seis espécies de $C x$. (Microculex) obtidas são relatadas pela primeira vez no Estado de Santa Catarina, e as seis espécies de Wyeomyia (Phoniomyia) são relatadas pela primeira vez em bromélias neste estado.

PALAVRAS-CHAVE. Mata Atlântica, fitotelmata, Anopheles, Wyeomyia, Culex.

The bromeliad-associated fauna includes mosquitoes and several other animals. Although immature forms of 214 species of culicids have been found in bromeliads (FrANK \& CURTIS, 1981), most studies have been restricted to anophelines, due to their medical importance, not referring to other mosquitoes (COUTINHO et al., 1944; Downs \& Pittendrigh, 1946). Aedes albopictus (Skuse, 1894) and other species were recorded in bromeliads at São Paulo State, but that species is more abundant in human-modified environments (MARQuEs et al., 2001). Aedes aegypti (Linnaeus, 1762) also was found in bromeliads, mostly near houses, in the State of Espírito Santo (VAREJÃO et al., 2005). The adaptation of immature mosquitoes to bromeliads depends on the species of the plant, as shown in Florida, where there were no larvae of Ae. aegypti, Ae. albopictus and Culex quinquefasciatus Say, 1823 in the native species of bromeliads, while those introduced species of bromeliads were infested by these mosquitoes (O'Meara et al., 2003).

There are many reports on the finding of mosquitoes in bromeliads (Frank \& CURTIS, 1981), including all 26 Wyeomyia (Phoniomyia) spp. (CORREA \& RAMALHO, 1956). All the species in this group have been found exclusively in bromeliads, except Wyeomyia (Phoniomyia) quasilongirostris (Theobald, 1907), which was also found in axils of other plants (FRANK \& CURTIS, 1981). However, since bromeliads have a diversified fauna, all the mosquitoes living in them must be identified, to get a better knowledge of their ecology.

The mosquito fauna associated to three species of bromeliads from rain forest and "restinga" at Santa Catarina Island was studied.

\section{MATERIAL AND METHODS}

The study was developed at two localities in the North of Santa Catarina Island, southern Brazil. The first one, Environment Conservation Unit Desterro (UCAD), has 495 ha and its headquarters are situated at $27^{\circ} 31^{\prime} 50.8^{\prime \prime} \mathrm{S} ; 48^{\circ} 30^{\prime} 44.3^{\prime \prime} \mathrm{W}$. UCAD is mostly constituted of secondary rain forest, in several stages of regeneration. Bromeliads are very common and diversified in the area, 
and they can attain even 200 individuals $/ 100 \mathrm{~m}^{2}$ in some parts (L. C. Pinho, pers. commun.). The other locality, Morro das Aranhas Particular Reserve of Natural Patrimony (RPPNMA), is situated in the northeast of the island, near the Costão do Santinho Resort. It is a sandy and hilly area ("restinga").

The study was carried out from May 2004 to April 2005 , by examining ten plants per month of Vriesea philippocoburgi Wawra and ten of Aechmea lindenii (E. Morren) Baker var. lindenii at UCAD, besides ten of $A$. lindenii var. lindenii and ten of Vriesea friburgensis $\mathrm{Mez}$ var. paludosa (L. B. Smith) at RPPNMA.

The species of bromeliads were chosen according to references to high frequencies of anophelines (Reitz, 1983 ) and to their abundance in the area. Genera and subgenera were abbreviated as proposed by REINERT $(1975,1982,1991)$.

As Lozover \& Silva (1999) related the absence of significant differences between the results by dismounting and washing the plants' leaves and by sucking their water, the last method was used in the present study. The water was sucked with a siphon bottle, blowing in the tank to mix the material, adding more pure water to the plants and repeating the suction. All the material was poured out in a translucent white plastic tray, in parcels small enough to see the immature forms. The larvae were collected with a plastic disposable pipette, if necessary illuminating from below or from above with a small torch. The water was then put back in the bromeliad, to reduce the environmental disturbance. In the laboratory, larvae were separated into small vials, mixing the original water with distilled water, periodically adding powdered fish food, previously diluted in water. The small vials were kept in $350 \mathrm{ml}$ plastic vials, covered with voile. The $4^{\text {th }}$ instar larval and the pupal exuviae were preserved in ethanol $80^{\circ} \mathrm{GL}$, mounted on slides and studied. Adults were preserved dry, fixed to triangles on entomological pins. Male genitalia were dissected and mounted, for the identification.

Adult mosquitoes were identified based on КUмm (1933), Rozeboom \& Komp (1950), Lane \& Whitman (1943), Correa \& Ramalho (1956), Cotrim \& Galati (1977) and ForATtinI (2002). All the material was deposited in the collection of Microbiology and Parasitology Department of Universidade Federal de Santa Catarina, at Florianópolis, and voucher specimens were donated to the collection of Faculdade de Saúde Pública, Universidade de São Paulo, São Paulo, Brazil (Dr. Iná Kakitani).

Mean temperatures and precipitation during the study period were recorded at Station 124 of Epagri/ INMET, located at the nearby municipality of São José, SC (27 $\left.36^{\prime} 07^{\prime \prime} \mathrm{S} ; 48^{\circ} 37^{\prime} 11^{\prime \prime} \mathrm{W}\right)$. The correlation index of Spearman (SiEgel, 1975) was used to analyse the correlation of abundance of mosquitoes with the climatic conditions. The results of species of bromeliads were compared by qui-square test(Gomes, 1982).

\section{RESULTS}

Immature mosquitoes could easily be seen, even in cloudy days in the forest, by using small flash light on the tray; the small pupae of Culex (Microculex) spp. moved very fast, and their collection was difficult.

A total of 368 immature forms were obtained from $V$. friburgensis and $A$. lindenii at the RPPMA and $V$. philippocoburgi, but none from A. lindenii at UCAD (Tab. I). From that total, 291 (79.8\%) were Culex (Microculex) spp., 66 (17.93\%) Wyeomyia (Phoniomyia) spp., five (1.36\%) Anopheles (Kerteszia) cruzii (Dyar \&

Table I. Abundance of immature mosquitoes collected in bromeliads at two areas of Santa Catarina Island, southern Brazil, from May 2004 to April $2005\left(^{*}, \chi^{2}=103.4>>\chi_{\text {tab, } 11 \text { d.f. } 5 \%}^{2}=19.68 ;{ }^{\S}, \chi^{2}=99.32>>\chi^{2}\right.$ tab, 11 d.f., $5 \%=19.68 ;{ }^{*}, \chi^{2}=54.3>>\chi^{2}$ tab, 11 d.f., $5 \%=19.68$; no mosquito was collected in the examined Vriesea philippocoburgi at UCAD).

\begin{tabular}{|c|c|c|c|c|c|c|c|c|}
\hline \multirow{3}{*}{$\begin{array}{l}\text { Localities } \\
\text { Bromeliads } \\
\text { Species of mosquitoes }\end{array}$} & \multicolumn{4}{|c|}{ RPPNMA } & \multirow{2}{*}{\multicolumn{2}{|c|}{$\frac{\text { UCAD }}{\text { Vriesea philippocoburgi }^{\$ \#}}$}} & \multirow{2}{*}{\multicolumn{2}{|c|}{$\begin{array}{l}\text { Total for } \\
\text { both areas }\end{array}$}} \\
\hline & \multicolumn{2}{|c|}{ Aechmea lindenii*\# } & \multicolumn{2}{|c|}{ Vriesea friburgensis $* \S$} & & & & \\
\hline & $\mathrm{N}$ & $\%$ & $\mathrm{~N}$ & $\%$ & $\mathrm{~N}$ & $\%$ & $\mathrm{~N}$ & $\%$ \\
\hline Anopheles (Kerteszia) cruzii & - & 0.0 & - & 0.0 & 5 & 3.1 & 5 & 1.4 \\
\hline Culex (Microculex) group imitator & 37 & 32.7 & 21 & 22.3 & 52 & 32.3 & 110 & 29.9 \\
\hline Culex (Microculex) hedys & - & 0.0 & 2 & 2.1 & 1 & 0.6 & 3 & 0.8 \\
\hline Culex (Microculex) imitator & 16 & 14.2 & 1 & 1.1 & 53 & 32.9 & 70 & 19.0 \\
\hline Culex (Microculex) neglectus & - & 0.0 & 3 & 3.2 & - & 0.0 & 3 & 0.8 \\
\hline Culex (Microculex) series pleuristriatus & 4 & 3.5 & 48 & 51.1 & 16 & 9.9 & 68 & 18.5 \\
\hline Culex (Microculex) albipes & 1 & 0.9 & 2 & 2.1 & 1 & 0.6 & 4 & 1.1 \\
\hline Culex (Microculex) davisi & 5 & 4.4 & 11 & 11.7 & 8 & 5.0 & 24 & 6.5 \\
\hline Culex (Microculex) pleuristriatus & 2 & 1.8 & 5 & 5.3 & 2 & 1.2 & 9 & 2.4 \\
\hline Wyeomyia (Phoniomyia) davisi & - & 0.0 & - & 0.0 & 3 & 1.9 & 3 & 0.8 \\
\hline Wyeomyia (Phoniomyia) edwardsi & 1 & 0.9 & - & 0.0 & - & 0.0 & 1 & 0.3 \\
\hline Wyeomyia (Phoniomyia) incaudata & 31 & 27.4 & 1 & 1.1 & 9 & 5.6 & 41 & 11.2 \\
\hline Wyeomyia (Phoniomyia) pallidoventer & - & 0.0 & - & 0.0 & 4 & 2.5 & 4 & 1.1 \\
\hline Wyeomyia (Phoniomyia) pilicauda & 10 & 8.8 & - & 0.0 & 6 & 3.7 & 16 & 4.4 \\
\hline Wyeomyia (Phoniomyia) tripartita & 1 & 0.9 & - & 0.0 & - & 0.0 & 1 & 0.3 \\
\hline Toxorhynchites sp. & 5 & 4.4 & - & 0.0 & 1 & 0.6 & 6 & 1.6 \\
\hline TOTAL & 113 & 100.0 & 94 & 100.0 & 161 & 100.0 & 368 & 100.0 \\
\hline
\end{tabular}


Knab, 1908) and six Toxorhynchites sp. (1.63\%). Culex (Microculex) imitator Theobald, 1903 was the most abundant species (19.0\%), besides $C x$. (Mcx.) group imitator (29.9\%). Several immatures of Culex (Microculex) spp. and of Toxorhynchites could not be identified to species level, because they died before becoming adults or because only females were obtained. Anopheles cruzii was recorded only in the autumn and winter, which include the coolest and less rainy months, whereas Cx. imitator, Culex davisi Kumm, 1933 and Wyeomyia incaudata (Root, 1928) were collected almost all year round (Tab. III).

Abundance of mosquitoes, separated by species (Tab. I) or grouped by genera (Tab. II) collected in $A$. lindenii in RPPNMA were significantly different of those collected in $V$. friburgensis and V. philippocoburgi, and those collected from both species of Vriesea $(V$. friburgensis from RPPNMA and V. philippocoburgi from UCAD) also were significantly different. Culex (Microculex) spp. constituted $57.52 \%$ of the insects from A. lindenii, versus $98.9 \%$ from $V$. friburgensis, and $W y$. incaudata and Wyeomyia pilicauda (Root, 1928) were much more common in $A$. lindenii.
The number of immature mosquitoes collected in phytotelmata of $V$. philippocoburgi was positively related to the rainfall $(r=0.591, p>0.05=0.143)$; no other correlation with temperature or rain was significant.

\section{DISCUSSION}

The mean number of immature forms per plant in the present study $(0.77$, or 1.02 , if data of $A$. lindenii from UCAD is eliminated) is smaller than that of Aedes albopictus (Skuse, 1894) in bromeliads (species not cited) from Ilhabela (G. R. Marques, unpublished data). The results indicate a great predominance of Culex (Microculex) spp. in all the species of bromeliads. The proportion of Culex (Microculex) spp. in the bromeliads at UCAD (90.22\%) is a little higher than that observed by MARques et al. (2001) in bromeliads far from houses in Ilhabela, which was $78.9 \%$ (of 10,987 mosquitoes). In bromeliads studied by these authors in gardens and backyards the proportion of the group was also similar $(76.2-78.3 \%)$. Therefore, this high proportion of mosquitoes of the group seems to be common in bromeliads in several environments. The great specific

Table II. Abundance of immature mosquitoes, grouped by genera, collected in bromeliads at two areas of Santa Catarina Island, southern Brazil, from May 2004 to April $2005\left(*, \chi^{2}=48.7>>\chi_{\text {tab, } 3 \text { d.f., } 5 \%}^{2}=7.82 ;{ }^{\S}, \chi^{2}=15.7>\chi_{\text {tab, } 3 \text { d.f., } 5 \%}^{2}=7.82 ; \#, \chi^{2}=45.6>>\chi_{\text {tab, } 3 \text { d.f., } 5 \%}^{2}=7.82\right)$.

\begin{tabular}{|c|c|c|c|c|c|c|c|c|}
\hline \multirow{3}{*}{$\begin{array}{l}\text { Localities } \\
\text { Bromeliads } \\
\text { Species of mosquitoes }\end{array}$} & \multicolumn{4}{|c|}{ RPPNMA } & \multirow{2}{*}{\multicolumn{2}{|c|}{$\frac{\text { UCAD }}{\text { Vriesea philippocoburgi } i^{\S \#}}$}} & \multirow{2}{*}{\multicolumn{2}{|c|}{$\begin{array}{l}\text { Total for } \\
\text { both areas }\end{array}$}} \\
\hline & \multicolumn{2}{|c|}{ Aechmea lindenii*\# } & \multicolumn{2}{|c|}{ Vriesea friburgensis $* \S$} & & & & \\
\hline & $\mathrm{N}$ & $\%$ & $\mathrm{~N}$ & $\%$ & $\mathrm{~N}$ & $\%$ & $\mathrm{~N}$ & $\%$ \\
\hline Anopheles (Kerteszia) cruzii & - & 0.0 & - & 0.0 & 5 & 3.1 & 5 & 1.4 \\
\hline Culex (Microculex) spp. & 65 & 57.5 & 93 & 98.9 & 133 & 82.5 & 291 & 79.0 \\
\hline Wyeomyia (Phoniomyia) spp. & 43 & 38.0 & 1 & 1.1 & 22 & 13.7 & 66 & 18.1 \\
\hline Toxorhynchites sp. & 5 & 4.4 & - & 0.0 & 1 & 0.6 & 6 & 1.6 \\
\hline TOTAL & 113 & 100.0 & 94 & 100.0 & 161 & 100.0 & 368 & 100.0 \\
\hline
\end{tabular}

Table III. Presence of mosquitoes in monthly collections at bromeliads and mean temperature and rainfall in Santa Catarina Island, from May 2004 to April 2005.

\begin{tabular}{|c|c|c|c|c|c|c|c|c|c|c|c|c|}
\hline Species/ months & May & Jun & Jul & Aug & Sep & Oct & Nov & Dec & Jan & Feb & Mar & Apr \\
\hline Anopheles (Kerteszia) cruzii & - & + & + & - & - & - & - & - & - & - & + & + \\
\hline Culex (Microculex) group imitator & + & + & + & + & + & + & + & + & + & + & + & + \\
\hline Culex (Microculex) hedys & - & + & - & - & - & - & - & - & - & - & - & + \\
\hline Culex (Microculex) imitator & - & + & + & + & - & + & + & + & + & + & + & + \\
\hline Culex (Microculex) neglectus & - & - & - & - & - & - & + & - & - & - & - & - \\
\hline Culex (Microculex) series pleuristriatus & + & + & + & + & + & + & + & + & - & + & + & + \\
\hline Culex (Microculex) albipes & + & - & - & - & - & - & - & - & - & + & - & + \\
\hline Culex (Microculex) davisi & + & + & + & + & + & + & + & + & - & + & - & + \\
\hline Culex (Microculex) pleuristriatus & - & + & - & - & - & + & - & - & - & + & - & + \\
\hline Wyeomyia (Phoniomyia) davisi & - & - & + & - & - & - & - & - & - & - & - & + \\
\hline Wyeomyia (Phoniomyia) edwardsi & - & + & - & - & - & - & - & - & - & - & - & - \\
\hline Wyeomyia (Phoniomyia) incaudata & + & + & + & + & - & - & + & + & + & + & + & + \\
\hline Wyeomyia (Phoniomyia) pallidoventer & + & - & + & - & - & + & - & - & - & - & - & + \\
\hline Wyeomyia (Phoniomyia) pilicauda & - & + & + & - & - & - & + & + & + & + & - & + \\
\hline Wyeomyia (Phoniomyia) tripartita & - & - & + & - & - & - & - & - & - & - & - & - \\
\hline Wyeomyia (Phoniomyia) sp. & + & + & + & + & - & + & + & + & + & + & + & + \\
\hline Toxorhynchites sp. & - & + & + & - & + & - & - & - & + & - & + & + \\
\hline Mean temperature $\left({ }^{\circ} \mathrm{C}\right)$ & 18.0 & 17.6 & 16.2 & 17.3 & 19.9 & 19.7 & 21.9 & 23.4 & 25.3 & 24.7 & 24.8 & 23.1 \\
\hline Rainfall (mm) & 214.1 & 92.5 & 83.2 & 28.3 & 127.8 & 134.7 & 130.1 & 260.6 & 211.9 & 222.1 & 134 & 164.3 \\
\hline
\end{tabular}


diversity of Culex (Microculex) in bromeliads was also observed in Venezuela (MACHADO-AlLISON et al., 1986). Mosquitoes of this group bite frogs (LOURENÇO-DE-OLIVEIRA \& HEYDEN, 1986), and there is no indication of any medical importance for them. In morning collections at UCAD, these mosquitoes were very rarely seen landing on humans $(0.3 \%)$ (PAterno \& Marcondes, 2004); they were absent or very uncommon in similar collections by ForATTINI et al. (1981, 1986) in the south of the State of São Paulo, at different times of the day.

In studies carried out in Venezuela (MACHADOAllison et al., 1986) and in Ilhabela (G. R. Marques, pers. commun.), the predominant species was Culex (Microculex) pleuristriatus Theobald, 1903, contrasting with the present observations, in which $C x$. (Mcx.) imitator was the most common species. If all the $C x$. (Mcx.) series Pleuristriatus could be identified to species level, these proportions would probably change.

Wyeomyia (Phoniomyia) spp., as a group, were relatively uncommon in the bromeliads, compared to Culex (Microculex), but Wy. incaudata and Wy. pilicauda are more common than some species of the last group; if all the specimens of Culex (Microculex) could be identified to the species level, this order would certainly be different. Ten species of Wyeomyia (Phoniomyia) were reported biting humans and one more, Wy. quasilongirostris, in bromeliads in UCAD (MARCONDES et al., 2003; PATERNO $\&$ Marcondes, 2004). Some of these mosquitoes have been incriminated as vectors of arboviroses (CORREA \& RAMALHo, 1956; Souza Lopes et al., 1975).

Anopheles (Kerteszia) cruzii, an important vector of malaria in the southern part of the Atlantic Forest in Brazil (ForATTINI, 2002), constituted a very small part of the mosquito fauna, and was much less common in the studied bromeliads than previously reported in the State of Santa Catarina (REITz, 1983). Species of this genus also constituted only $1 \%$ of the mosquitoes in bromeliads at Ilhabela, State of São Paulo, and were commoner from March to October (G. R. Marques, pers. commun).

Although larvae of Anopheles (Kerteszia) spp. have been found in bromeliads containing only $10 \mathrm{ml}$ of water, they are much more common in those containing more water (FoRATTINI, 2002). There are no data on the conditions necessary for the development of other mosquitoes in bromeliads; they have been only recorded in these phytotelmata, usually with no identification of the plant. The number of Anopheles collected was small, and they were obtained only in $V$. philippocoburgi, which was not very exposed to sunlight and wind; this exposition is considered inconvenient to the development of these mosquitoes (Reitz, 1983; ForatTini, 2002). The proportion of bromeliads with immature forms of $A n$. cruzii is much smaller than previously observed in southern Brazil, respectively $15.9 \%$ (RACHOU \& FERREIRA, 1946) and $17.9 \%$ (RACHOU et al., 1949). The reasons for such difference should be investigated, and several factors are probably involved.

The prevalence of Anopheles in $V$. friburgensis is much smaller than referred by REITz (1983) for studies in the State of Santa Catarina. In the old studies, usually the plants were broken-up and all the material was examined. In the present study, the plants were only washed and sucked, and this could influence the results. However, the results obtained by this method are not significantly different of those obtained by the dismounting of the plants (LozOvEI \& SiLVA, 1999); these authors studied mostly Aechmea cylindrata Lindman, 1891 and Vriesea platynema Gaud, 1843 in Quatro Barras (Paraná, $910 \mathrm{~m}$ a. s. 1.), and did not inform the species of the mosquitoes.

The absence of immature mosquitoes in $A$. lindenii (120 plants) observed in UCAD contrasts with their presence in the same plant species in RPPNMA. In the relatively dark forest these plants have open rosettes, formed by relatively narrow leaves. Usually there were only dry rotting leaves in the tank, whereas in the "restinga" the plant leaves are shorter and wider (ca. 6 $\mathrm{cm}$ ) and held together, forming a narrow and deep tank, which usually contained visible water. These features probably accounted for the difference in the results. Therefore, the influence of the environment on the mosquito fauna in a species of bromeliad seems to be significant, and the prevalence of mosquitoes should be separately expressed for every studied environment. The significant differences between faunas in different species of bromeliads (Tabs. I, II) for the two localities (e.g., V. friburgensis vs. V. philippocoburgi) are probably caused by several factors, and are difficult to explain.

Vrisea friburgensis at RPPNMA had almost only Culex (Microculex), while A. lindenii had less Culex (Microculex) spp. and much more Wyeomyia spp. The difference between the faunas for the two species of bromeliads may be related to the disposition of the leaves of the plant. In fact, in this locality, the leaves of $A$. lindenii were grouped, forming one deep tank, containing more water, while the leaves of $V$. friburgensis formed several small tanks. Maybe the immature forms of Culex (Microculex), small and fragile, are more exposed, in one large cavity, to predators, or for any reason best adapted to small cavities, and the larvae of Wyeomyia could be less sensitive to them or best adapted to larger cavities. For example, larvae of Wyeomyia smithii (Coquillett, 1901) were much less exposed to predation by Metriocnemus knabi Coquillett, 1904 (Chironomidae) in tanks of Sarracenia purpurea Linnaeus than those of Ae. aegypti and Anopheles sp., possibly due to the long setae of the Wyeomyia larvae (PETERSEN et al., 2000). The greater populations of Leptagrion siqueirai Santos, 1968 (Odonata: Coenagrionidae) in Aechmea aquilega (Salisbury) Grisebach than in equal-sized Aechmea nudicaulis (Linnaeus) Grisebach was attributed to greater quantity of cavities in the first, providing many niches for the damselfly larvae (LouniBos et al., 1987). The separate influence of the species of bromeliad and of the environment, besides the relationship between mosquitoes and their predators in bromeliads, should be thoroughly studied.

All the six species of Culex (Microculex) are here recorded for the first time in the State of Santa Catarina, and all the six species of Wyeomyia (Phoniomyia) are here reported for the first time in bromeliads in this state. Only Wy. (Pho) quasilongirostris and Wyeomyia bourrouli (Lutz, 1905) (not in subgenus Phoniomyia), of the species belonging to this genus, had been reported 
in bromeliads in this state (MARCONDES et al., 2003). Wyeomyia (Phoniomyia) edwardsi (Lane \& Cerqueira, 1942) and Wyeomyia (Phoniomyia) tripartita (BonneWebster \& Bonne, 1921) were reported for the first time in the State of Santa Catarina biting humans by Marcondes et al. (2003). Paterno \& Marcondes (2004) made a similar record for Wyeomyia (Phoniomyia) davisi (Lane \& Cerqueira, 1942), Wyeomyia (Phoniomyia) pallidoventer (Theobald, 1907) and Wy. pilicauda. CARDOSO et al. (2005) reported, without mention on the method for the collection, the presence in the State of Rio Grande do Sul of Wyeomyia (Phoniomyia) lopesi (Correa \& Ramalho, 1956), Wy. davisi and Wy. quasilongirostris, the former not yet reported in Santa Catarina. These data indicate the great diversity of Culex (Microculex) and Wyeomyia (Phoniomyia) in southern Brazil, and the need of additional studies in the region.

The method for the examination of the material from bromeliads (and other samples of water), not previously described (SERvice, 1993), was very productive and practical, and should be compared to other methods.

Acknowledgements. To Mr. Silvanio Guilherme da Costa, for the help in the fieldwork at UCAD, to Drs. Maike Hering Queiroz (in memoriam) and Aldalea S. Prata, for the authorisation to the collections in UCAD, and to Costão do Santinho Resort, for the permission for the collections in RPPNMA. To Mr. Aristides Fernandes (Faculdade de Saúde Pública, USP, São Paulo), for checking some identifications. To an anonymous referee, for the useful suggestions. To CNPq (Proc.-690143/01-0) and FAPESC (Proc.-196/2003), for financial help.

\section{REFERENCES}

Cardoso, J. C.; Corseuil, E. \& Barata, J. M. S. 2005. Culicinae (Culicidae) ocorrentes no Estado do Rio Grande do Sul, Brasil. Revista Brasileira de Entomologia 49(2):275-287.

Correa, R. R. \& Ramalho, G. R. 1956. Revisão de Phoniomyia Theobald, 1903 (Diptera, Culicidae, Sabethini). Folia Clínica et Biológica 25:1-176.

Cotrim, M. D. \& Galati, E. A. B. 1977. Revisão da série Pleuristriatus do subgênero Microculex Theobald, 1907 (Diptera, Culicidae). Revista Brasileira de Entomologia 20(3/4):169-205

Coutinho, J. O.; Rachou, R. \& Ferreira, M. 1944. Considerações em torno de uma inspecção preliminar de malária em zona de alta endemicidade no Estado de Santa Catarina. Memórias do Instituto Oswaldo Cruz 41(1):1-19.

Downs, W. G. \& Pittendrigh, C. S. 1946. Bromeliad malaria in Trinidad, British West Indies. American Journal of Tropical Medicine 26(1):47-66

Forattini, O. P. 2002. Culicidologia Médica. São Paulo, EDUSP. $860 \mathrm{p}$.

Forattini, O. P.; Gomes, A. C.; Natal, D. \& Santos, J. L. F. 1986. Observações sobre atividade de mosquitos Culicidae em matas primitivas da planície e perfis epidemiológicos de vários ambientes no Vale do Ribeira, São Paulo, Brasil. Revista de Saúde Pública 20(3):178-203.

Forattini, O. P.; Gomes, A. C.; Santos, J. L. F.; Galati, E. A. B.; Rabello, E. X. \& Natal, D. 1981. Observações sobre a atividade de mosquitos Culicidae, em mata residual do Vale do Ribeira, S. Paulo. Revista de Saúde Pública 15:557-586.

Frank, J. H. \& Curtis, G. A. 1981. On the bionomics of bromeliadinhabiting mosquitoes. VI. A review of the bromeliad-inhabiting species. Journal of the Florida Anti-mosquito Association 52(1):4-23.

Gomes, F. P. 1982. Curso de estatística experimental. São Paulo, Nobel. 430p.

Kumm, H. W. 1933. Mosquitos breeding in bromeliads, at Bahia,
Brazil. Bulletin of Entomological Research 24(4):561-573 Lane, J. \& Whitman, L. 1943. Novas espécies de Culex do Brasil (Diptera, Culicidae). Revista de Entomologia 14(3):389-408.

Lounibos, L. P.; Frank, J. H.; Machado-Allison, C. E.; Ocanto, P. \& Navarro, J. C. 1987. Survival, development and predatory effects of mosquito larvae in Venezuelan Phytotelmata. Journal of Tropical Ecology 3:221-242.

Lourenço-de-Oliveira, R. \& Heyden, R. 1986. Alguns aspectos da ecologia dos mosquitos (Diptera: Culicidae) de uma área de planície no Rio de Janeiro. IV. Preferências alimentares e freqüência domiciliar. Memórias do Instituto Oswaldo Cruz 81(1): 15-27.

Lozovei, A. L. \& Silva, M. A. N. 1999. Análise comparativa entre métodos alternativo e convencional para amostras de mosquitos obtidos a partir de habitats fitotélmicos (Bromeliáceas), Floresta Atlântica, Serra do Mar, Paraná, Brasil. Revista Brasileira de Zoologia 16(4):957-966.

Machado-Allison, C. E.; Barrera, R.; Delgado, L.; Gómez-Cova, C. \& Navarro, J. C. 1986. Mosquitos (Diptera: Culicidae) de los fitotelmata de Panaquire, Venezuela. Acta Biologica Venezolana 12(2):1-12.

Marcondes, C. B.; Fernandes, A.; Paterno, U.; Müller, G. A.; Pinho, L. C. \& Struffaldi, D. V. 2003. New records of mosquitoes from the southern Brazilian states of Santa Catarina and Rio Grande do Sul, with 18 species new for the States (Diptera: Culicidae). Zootaxa 347:1-6.

Marques, G. R.; Santos, R. L. \& Forattini, O. P. 2001. Aedes albopictus em bromélias de ambiente antrópico no Estado de São Paulo, Brasil. Revista de Saúde Pública 35(3):243-248.

O'meara, G. F.; Cutwa, M. M. \& Evans, L. F., JR. 2003. Bromeliadinhabiting mosquitoes in south Florida: native and exotic plants differ in species composition. Journal of Vector Ecology 28(1):37-46.

Paterno, U. \& Marcondes, C. B. 2004. Mosquitos matutinos de atividade antropofílica em Mata Atlântica, Florianópolis, SC. Revista de Saúde Pública 38(1):133-135.

Petersen, R. L.; Faust, A.; Nagana, J.; Thomas, C. \& Vilmenay, A. 2000. Foreign mosquito survivorship in the pitcher plant Sarracenia purpurea - the role of the pitcher-plant midge Metriocnemus knabi. Hydrobiologia 439(1-3):13-19.

Rachou, R. G. \& Ferreira, M. O. 1946. Algumas observações sobre o índice larvário de anofelinos do subgênero Kerteszia em bromeliáceas e sua densidade larvária no sul do Brasil. A Folha Médica 20:1-9.

Rachou, R. G.; Ferreira, M. O. \& Ferraz, D. M. 1949. Da distribuição vertical dos criadouros dos anofelinos do sub-gênero Kerteszia, em condições experimentais. Revista Brasileira de Malariologia e Doenças Tropicais 1(1):34-38.

REINERT, J. D. 1975. Mosquito generic and subgeneric abbreviations (Diptera: Culicidae). Mosquito Systematics 7(2):105-110. 1982. Abbreviations of generic and subgeneric taxa established since 1975. Mosquito Systematics 14(2):124-126. . 1991. Additional abbreviations of mosquito subgenera: names established since 1982 (Diptera: Culicidae). Mosquito Systematics 23(3):209-210.

Reitz, R. 1983. Bromeliáceas e a malária - bromélia endêmica. Itajaí, Herbário Barbosa Rodrigues. 808p.

Rozeboom, L. E. \& Komp, W. H. W. 1950. A new Microculex, elongatus, from Colombia, with notes on the subgenus. Proceedings of the Entomological Society of Washington 52(3): 147-157.

Service, M. W. 1993. Mosquito ecology: field sampling methods. London, Chapman \& Hall. 988p.

Siegel, S. 1975. Estatística não-paramétrica. São Paulo, McGraw-Hill. 349p.

Souza Lopes, O.; Sacchetta, L. A.; Fonseca, I. E. \& Lacerda, J. P. 1975. Bertioga (Guama group) and Anhembi (Bunyamwera group), two new arboviruses isolated in São Paulo, Brazil. American Journal of Tropical Medicine and Hygiene 4(1):131-134.

Varejão, J. B.; Santos, C. B.; Rezende, H. R.; Bevilacoua, L. C. \& Falqueto, A. 2005. Criadouros de Aedes (Stegomyia) aegypti (Linnaeus, 1762) em bromélias nativas na Cidade de Vitória, ES. Revista da Sociedade Brasileira de Medicina Tropical 38(3):238-240. 